\title{
Subacute Intervillous Thrombus
}

National Cancer Institute

\section{Source}

National Cancer Institute. Subacute Intervillous Thrombus. NCI Thesaurus. Code

C117328.

A focus of maternal thrombus within the placental intervillous space, often with peripheral villous compression, which is 3-5 days in age. 